\title{
The time has come; good-bye to all this
}

\author{
Colin Ratledge
}

Published online: 15 November 2017

(C) Springer Science+Business Media B.V., part of Springer Nature 2017

Biotechnology Letters first appeared in 1979 being the brain child of John Bu'Lock possibly the most eminent biotechnologist in academia at that time. John's untimely death came in January 1996 and it then fell upon myself to take over as Editor in Chief. Now, having reached the age of 81 , it is time for me to pass the baton on to my successor, Professor Chris Hewitt at Aston University, UK.

It has been a fascinating time to be an editor and to lead Biotechnology Letters. Initially, the journal was printed directly from authors' manuscripts; word processors were just appearing at this stage but each paper appeared in the format in which it left the author's typewriter. This, however, meant that this journal could truly claim to be the fastest in the world at publishing authors' papers-sometimes just 2 weeks between receiving the paper and it appearing in an issue of the journal. And, remember this was in days before emailing so all papers appearing in an issue had to be sent by snail mail to the editor and then finally to the printers. It was a demanding schedule both then and remains so today.

To-day, with the advent of computer technology, the speed at which papers can be sent around the world is staggering. Papers can be blasted out on any PC or Mac, sent off to a journal and then just wait for

C. Ratledge ( $\square)$

University of Hull, Hull, UK

e-mail: c.ratledge@hull.ac.uk evaluation. What could be easier? In fact, it is all too easy. Regretfully, this journal and many others receive papers from authors who simply have not bothered to check whether their paper fits in with the style or scope of the journal. All too easy just to hit the Send button and off the paper goes. Who cares if the editor objects to the writing, the style or non-style of the presentation? Who cares if it gets rejected, there are always dozens of other journals that the paper can be sent to. This carelessness and lack of thought is a worrying trend. Of course, authors want their papers to be published as fast as possible-preferably last week if this could be arranged. But spending more time ensuring that the paper is written correctly and is in the correct format required by the journal in question would, in the long run, save everyone a lot of time. But authors needs to remember that whilst it might only take them about $10 \mathrm{~min}$ to upload their paper into a journal's in-box, the editors can be ever faster in rejecting an imperfect, badly written and presented paper. Almost every editor for every journal is armed with a series of reject letters from which it only takes a few seconds to select the right one and then hit the Reject button.

When Biotechnology Letters first started it had a rejection rate of about $10 \%$; today we have a staggering rejection rate of nearly $85 \%$. About half of these rejections are simply because the subject matter of the paper is outside the scope of the journal or the paper itself is being presented in a format that 
does not comply with the journal's requirements. A moment's thought by the authors would save them from the inevitable rejection notice and possible embarrassment with their colleagues. But, seemingly, few authors are now bothered with a rejection: there are always lots of other journals out their waiting to receive their work.

Publishing at all costs does no one any good. Time was when papers were only written when authors had something useful to communicate to the outside world and they believed that some genuine progress had been made on a topic that they had spent some time researching in their labs. Today, too many papers are coming from graduate students desperate to achieve the required number of published papers in order to get their $\mathrm{PhD}$ or MSc degree. No matter if the work is uninspired, solves no problem and advances knowledge not one jot; it's the publication that matters not the content of the paper. I shudder to think how many papers I have had to deal with where I have had to write the rejection letter indicating that the entire work was a complete waste of time. It should never have started. The supervisor of the work in an academic institute, and it is always an academic writing the paper, seems to consider that any work done in a laboratory can be classed as scientific research and will have innate and lasting value. No so. In far too many cases, academics have carried out research projects that are simple process developments, routine investigations or highly derivative work that could be done by anyone. In many cases, it is work that will already have been done by industrial companies. How anyone could believe that optimizing the production of an enzyme, an antibody or a recombinant protein will be original research has always escaped me. Any product that is already in commercial production will have had that production process optimized by the production company. So why do academics try to do the work of industrialists? Certainly, I have never found the answer to this question.

Research is about solving problems, answering questions, developing hypotheses, working out how things behave and how and why they happen. It is not about trying to re-invent the wheel, trying to improve processes that are already in commercial production, isolating microorganisms or plants and finding that they have an unexceptional array of enzymes and metabolites. Scientists need to push back the frontiers of knowledge. There is no such thing as Pure Science and Applied Science; only Good Science and Bad Science. If you don't believe that your work is going to make a difference, then why are you doing it? And, having done the work, what are you going to do with it - apart from writing a paper? Will anyone else be interested? Does it open up new ideas for others? These are the sorts of question that need to be asked before any project begins never mind when it is finished.

But this journal has published many good, and some very good, papers over the years: too many to list and it would be invidious to mention any in particular as this might upset those who did not get a mention. The journal clearly serves a need in the scientific publishing world; the rapidity by which we have been able to assess papers and give authors a decision is, I believe, second to none. Our current average time to reach a decision is 12 days. No other journal appears to be able to match this. This is clearly important to our contributors and this is reflected in the quality of the papers that we are now publishing which has been steadily rising as indicated by our Impact Factor and other algorithms designed to indicate the success of a journal. The journal has always prided itself on its speed to handle and publish papers. This was one of the key reasons that John Bu'Lock originally started the journal and continues to be one of the primary reasons the journal continues today. It then becomes an exacting task for us to maintain and uphold that original conceptual idea.

It is also important to recognize that over the past years the journal has expanded its coverage of biotechnology to encompass new areas including animal cell technology, that continues to attract many papers concerned with aspects of cancer biotechnology, as well as now having specialized areas covering the environment, biofuels, plant cell technology, bioprocessing and also regenerative medicine and tissue engineering. These new sections reflect the expansion that biotechnology itself has made in so many different areas. Areas that are then reflected in the expanding scope of this journal. We also know that the journal is highly respected in industrial circles where our coverage of topics is often of significance to those who work in commercial organisations. It is good to know that we are wanted by the very people on whom biotechnology depends for fulfilling the production of so many products and carrying out so many processes and treatments. We go from strength to 
strength; not just because of the editors and editorial board members but because of those who contribute their work to us. We receive upwards of 1500 papers every year which is an indication of how many people believe that we are the best journal to publish their work. Our aim, as always, is to ensure that biotechnology prospers and grows. The future for the journal is bright because the future of biotechnology is bright.

Leaving the journal is not an easy task as its editing has been a major part of my scientific life for over 20 years; much longer if you include all the other journals in which I have played an editorial role. In leaving, I do owe a considerable debt of gratitude to a splendid team of executive editors and editorial board members, both present and past, who have almost without exception been a tremendous team of colleagues to work with and consult for their invaluable expertise and advice. It has been a great pleasure to work with them. I do thank them all most sincerely. But most of all, my deepest gratitude goes to Mrs Elizabeth Sparke who has been my secretary ever since I took over the reins of being editor in chief. She has been an absolute stalwart. If anyone can be said to run a journal, then it has to be the secretary. Someone who knows everything about every paper and almost every author and editor. To her goes my especial and deepest appreciation and thanks for all that she has done; for working almost every day of the year and being able to sort out the million and one problems that always beset an editor. Thank you so much, Elizabeth.

I leave the journal in the very capable hands of Professor Chris Hewitt who has a breadth of knowledge of biotechnology that will stand him in good stead over the many years that I hope he will be in charge of the journal. He will be only the third editor in chief in reaching 40 years of publication. I wish him every success and have every confidence that he will lead Biotechnology Letters to a bright and prosperous future that will continue to serve the scientific community of biotechnologists. Because that it what it is all about: Biotechnology. 